June 2003 • NREL/TP-500-34364

\title{
Optimized Hydrogen and Electricity Generation from Wind
}

\section{L.J. Fingersh}

\section{National Renewable Energy Laboratory}

1617 Cole Boulevard

Golden, Colorado 80401-3393

NREL is a U.S. Department of Energy Laboratory

Operated by Midwest Research Institute $\bullet$ Battelle $\bullet$ Bechtel

Contract No. DE-AC36-99-G010337 


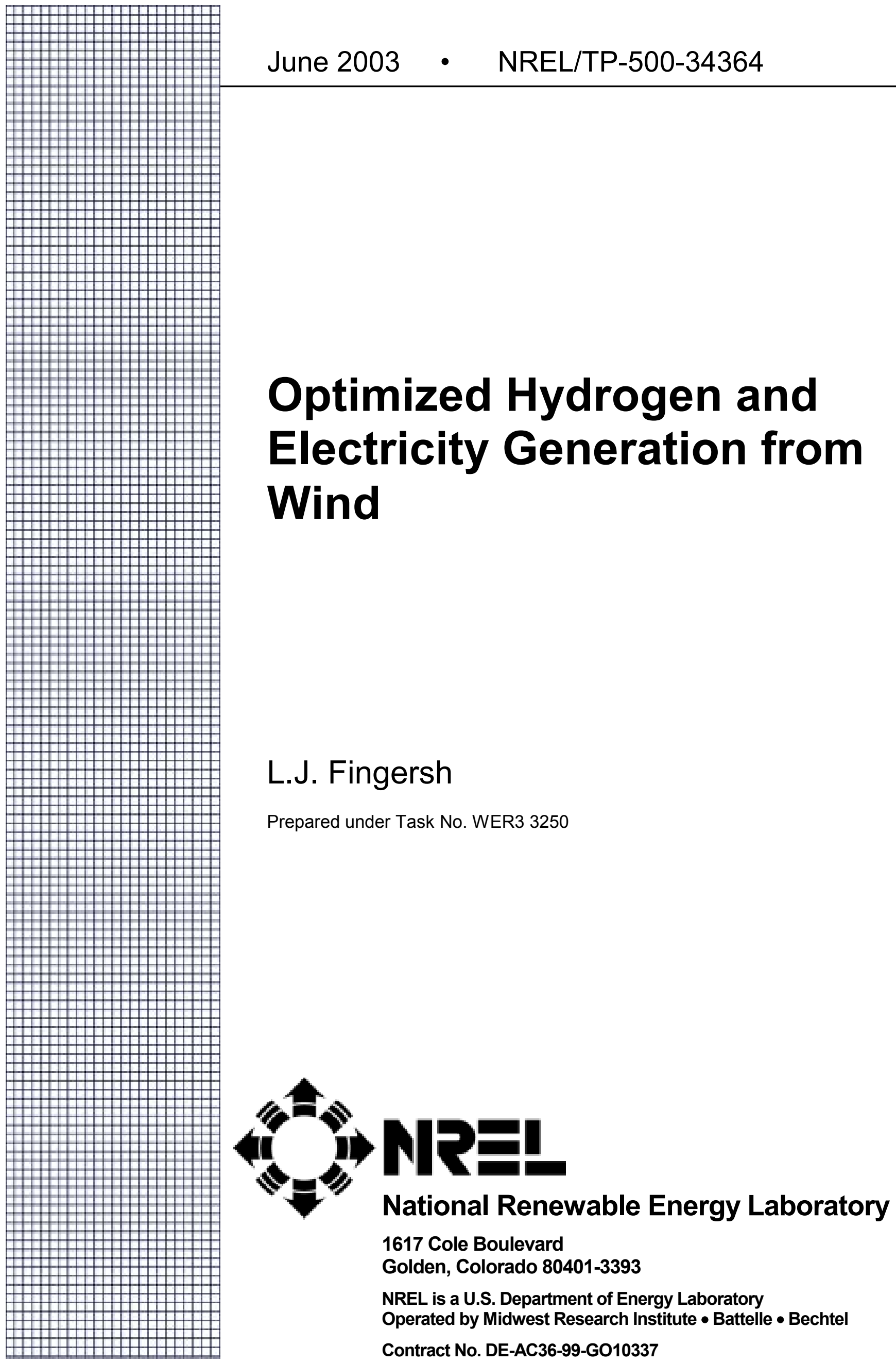




\section{NOTICE}

This report was prepared as an account of work sponsored by an agency of the United States government. Neither the United States government nor any agency thereof, nor any of their employees, makes any warranty, express or implied, or assumes any legal liability or responsibility for the accuracy, completeness, or usefulness of any information, apparatus, product, or process disclosed, or represents that its use would not infringe privately owned rights. Reference herein to any specific commercial product, process, or service by trade name, trademark, manufacturer, or otherwise does not necessarily constitute or imply its endorsement, recommendation, or favoring by the United States government or any agency thereof. The views and opinions of authors expressed herein do not necessarily state or reflect those of the United States government or any agency thereof.

Available electronically at http://www.osti.gov/bridge

Available for a processing fee to U.S. Department of Energy and its contractors, in paper, from:

U.S. Department of Energy

Office of Scientific and Technical Information

P.O. Box 62

Oak Ridge, TN 37831-0062

phone: 865.576 .8401

fax: 865.576.5728

email: reports@adonis.osti.gov

Available for sale to the public, in paper, from:

U.S. Department of Commerce

National Technical Information Service

5285 Port Royal Road

Springfield, VA 22161

phone: 800.553.6847

fax: 703.605.6900

email: orders@ntis.fedworld.gov

online ordering: http://www.ntis.gov/ordering.htm 


\section{TABLE OF CONTENTS}

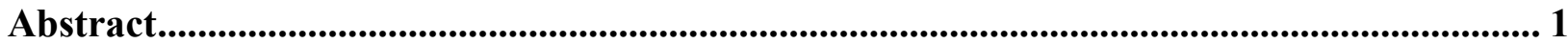

Electrolyzer Basics .................................................................................................................................. 1

Power Electronics Configurations........................................................................................ 2

The Tower as Storage ..................................................................................................................... 4

The Complete System (Including Regeneration) ........................................................................... 5

System Optimization.......................................................................................................................... 6

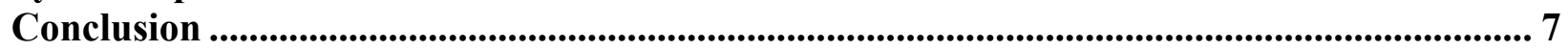




\section{Abstract}

Several optimizations can be employed to create hydrogen or hydrogen and electricity from a wind energy source. The key element in hydrogen production from any electrical source is an electrolyzer to convert water and electricity into hydrogen and oxygen. An electrolyzer is inherently a nearly constant, low-voltage, direct-current device requiring some form of control system and power electronics to connect to a high-voltage, alternating-current source of power.

Likewise, modern wind turbines employ a control system used in conjunction with power electronics in order to connect to the grid. It may be possible to use the turbine's controller and power electronics system to operate the electrolyzer as well, thereby eliminating component duplication. Such a coupled system would reduce the overall cost of independent stand-alone systems. Additionally, this approach would increase efficiency as only one electrical conversion (from $\mathrm{AC}$ to $\mathrm{DC}$ ), instead of three (from $\mathrm{AC}$ to $\mathrm{DC}$ to $\mathrm{AC}$ and back to $\mathrm{DC}$ ), would have to occur.

Electrical power provided to the electrolyzer in such a system would be controllable with excess power provided to the grid. Thus, a combined system would have more dispatchability than a wind-electric turbine alone. Such dispatchability might be used to provide the utility with a measure of control over the wind farm's total output that does not exist in current wind farms.

Produced hydrogen needs to be stored, transported, and/or regenerated into electricity offering additional synergies. For example, a wind turbine tower is generally a large-volume, cylindrical structure with sufficient wall-thickness to support storing hydrogen at substantial pressure. The turbine power electronics could also be used as a grid interface for a fuel cell or combustion-type electrical generation system and/or battery. This paper examines several coupled systems that offer enhanced capability, efficiency, and cost reduction opportunities over stand-alone component systems.

\section{Electrolyzer Basics}

An electrolyzer is usually composed of four basic components (Figure 1): the water supply, the power electronics, the controller, and the cell stack.

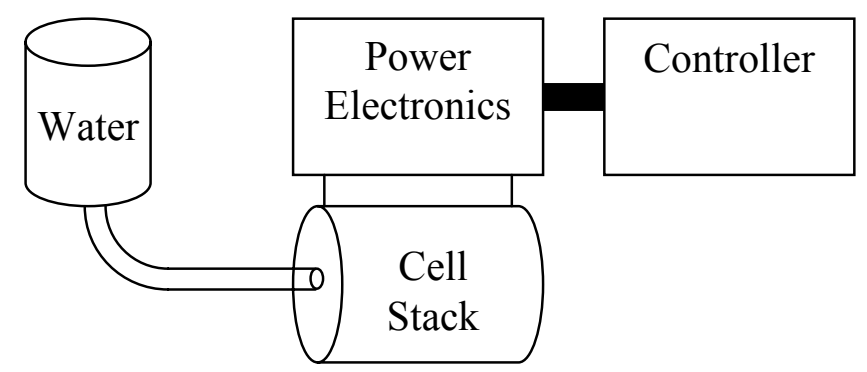

Figure 1. Basic electrolyzer configuration. 
An electrolyzer cell stack absorbs clean water and electricity and uses this electricity to split the water molecule into its constituent elements, hydrogen and oxygen. Electrically, the electrolyzer appears as a voltage source with a series resistor (Figure 2). A voltage source is simply a device with constant voltage independent of current flow. The terminal voltage of an electrolyzer will usually be proportional to the number of cells in series and to the temperature of the device. The resistance is a product of the ionic conductivity of the electrolyte and the electrical conductivity of the electrodes.

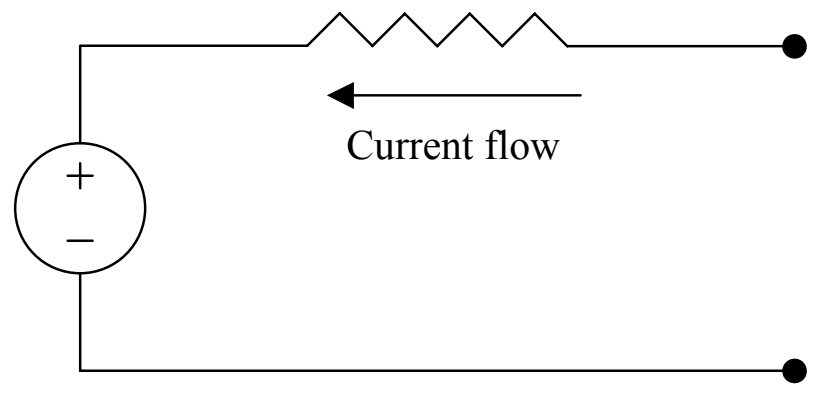

Figure 2 . Electrolyzer equivalent circuit.

In this configuration, the voltage of the electrolyzer is equal to about $1.5 \mathrm{~V}$ per cell plus the current times the equivalent resistance of the cell stack. As the current changes from zero to the rated current of the electrolyzer, the voltage increases linearly by about $10 \%$ to $20 \%$.

\section{Power Electronics Configurations}

A nearly infinite number of power electronics topologies can be used on a wind turbine. However, many share similar characteristics to the three in Figure 3. 

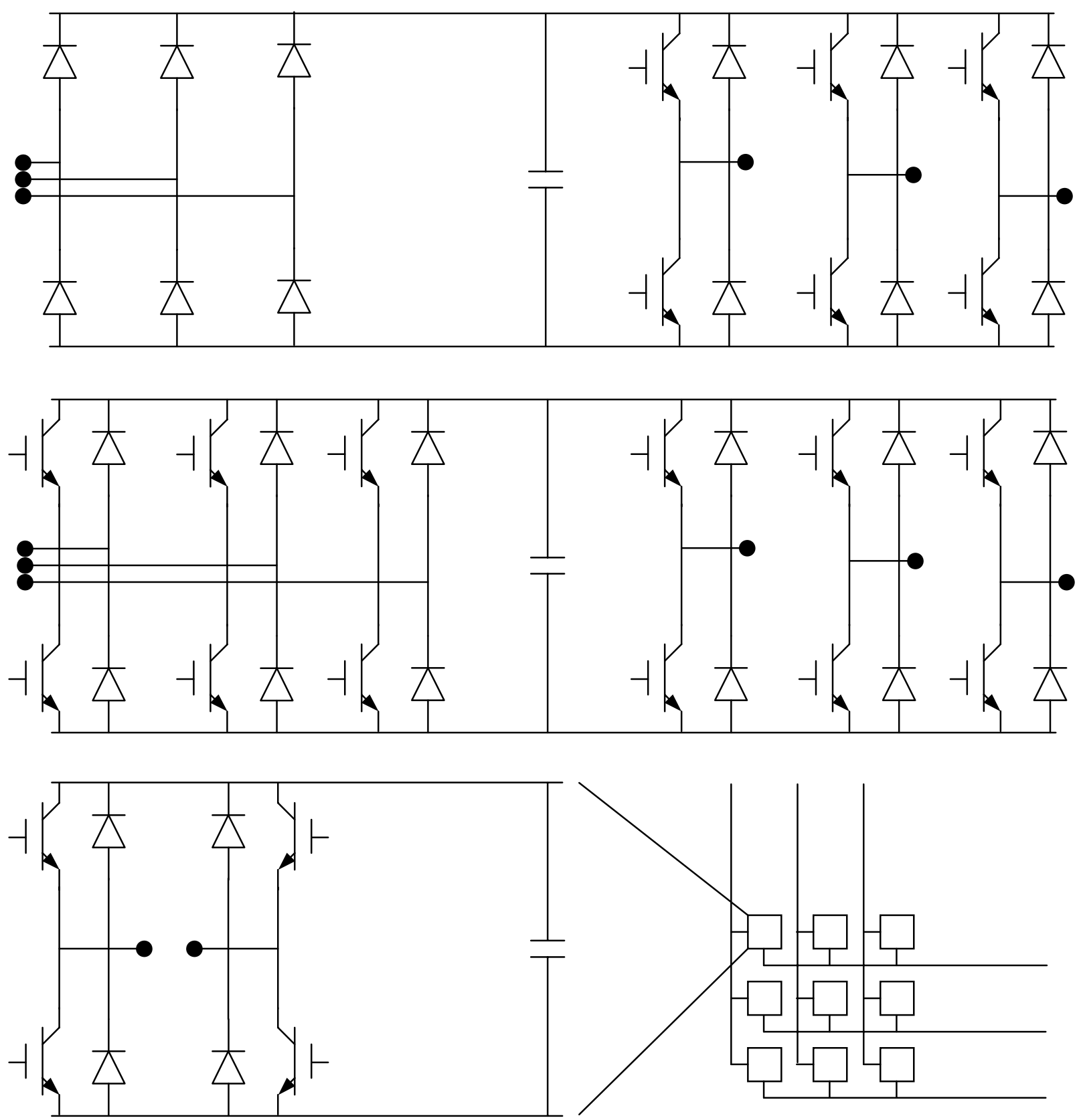

Figure 3 (a, b, c). Power electronics layouts.

In the first configuration (Figure 3a), a diode bridge is used as an interface to a permanent magnet or electrically excited synchronous generator. The DC bus voltage and the voltage on the capacitor are therefore proportional to the speed of the generator. Since the electrolyzer operates at a nearly constant voltage, the machine would have to operate at a nearly constant speed, thereby reducing the benefits of variable-speed operation. Therefore, this approach is probably undesirable. However, a DC-DC converter, such as a chopper, could be used between the electrolyzer and the DC bus, thereby decoupling the speed of the turbine from the voltage on 
the electrolyzer. This would add complexity but would provide separate controllability of the devices, which is highly desirable.

In the second configuration (Figure 3b), a full-processing or "back-to-back" converter is shown. This is likely the most common type of converter used on variable-speed wind turbines. The left bridge would either interface to a synchronous generator or to the rotor windings of a "doubly fed" or "wound-rotor" induction generator. Such a system would be capable of controlling the power flow to the grid separately from the DC bus voltage. If an electrolyzer were placed in parallel with the DC bus capacitor, the DC bus voltage would control its power. In this way, the turbine and electrolyzer could again be controlled separately.

In the third configuration (Figure 3c), a matrix-converter is shown. Each switch cell in the matrix uses an H-bridge, as shown on the left. Each H-bridge contains a DC capacitor whose voltage can be controlled. By placing an electrolyzer in parallel with each capacitor, the generator and electrolyzers could again be independently controlled. The additional complexity of many individual electrolyzers, rather than one large one, might not be a problem. Electrolyzers are usually composed of many individual cells stacked in series and connected in parallel. Therefore, the individual components of a standard electrolyzer would simply be connected to their individual matrix switches in this design rather than to each other.

In all cases, the turbine controller would be employed to control the electrolysis system. By eliminating the controller and power electronics systems from the electrolyzer, the cost of the electrolyzer could be reduced by approximately $30 \%$ to $50 \%$ (see Table 1) with little to no increase in the cost of the wind turbine. Additionally, efficiency would be increased because two power conversion steps (from the DC bus back to AC and from the AC grid back to DC) would be eliminated. Since each step results in a loss of approximately $3 \%$ to $5 \%$, an overall increase in efficiency of $6 \%$ to $10 \%$ can be expected.

Table 1. Electrolyzer Current and Projected Costs

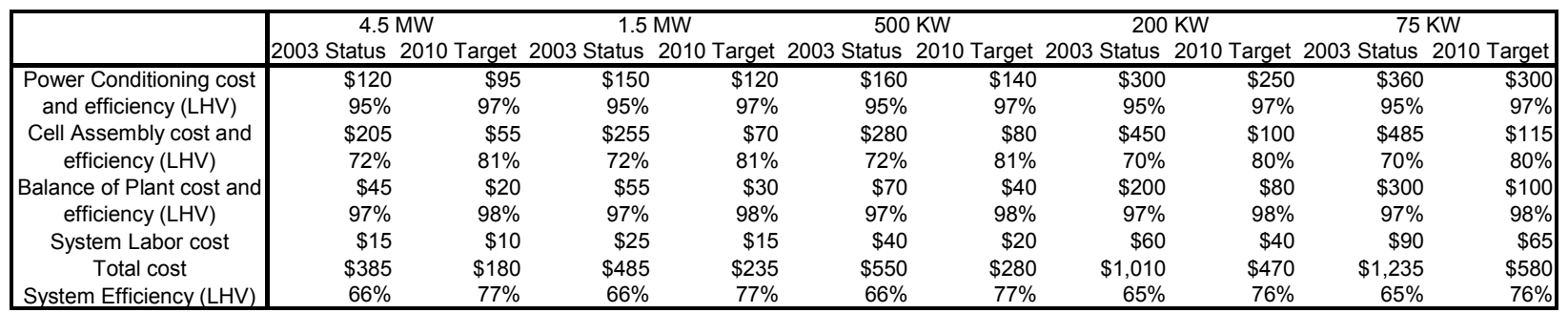

\section{The Tower as Storage}

The tower of a modern 1.5-MW wind turbine is usually 65 meters to 85 meters tall, tapered from five meters to two meters in diameter (bottom to top) with a wall thickness of about 25 millimeters to 36 millimeters. These towers contain $663.7 \mathrm{~m}^{3}$ to $867.9 \mathrm{~m}^{3}$ of volume. Assuming only two-thirds of this could be employed (so that caps could be placed at the top and bottom and equipment could still be housed in the base), $442.5 \mathrm{~m}^{3}$ to $578.6 \mathrm{~m}^{3}$ of volume could be enclosed as a hydrogen tank. Such a tank would hold at least 10 atmospheres of pressure permitting 4,425 
$\mathrm{Nm}^{3}$ to $5,786 \mathrm{Nm}^{3}$ of hydrogen storage. Assuming $11.1 \mathrm{Nm}^{3}$ of hydrogen equals $1 \mathrm{~kg}$ of hydrogen at standard temperature and pressure, $399 \mathrm{~kg}$ to $521 \mathrm{~kg}$ of hydrogen could be stored per tower. Hydrogen's lower heating value (LHV) is about $33.3 \mathrm{kWh} / \mathrm{kg}$, thus a $1.5-\mathrm{MW}$ wind turbine tower could store 13.3 MWh to 17.3 MWh (LHV) of hydrogen. If the electrolyzer is $80 \%$ efficient $(\mathrm{HHV}=39.4 \mathrm{kWh} / \mathrm{kg})$, it would take $49.25 \mathrm{kWh}$ to produce $1 \mathrm{~kg}$ of hydrogen. Therefore, a tower could store 13.1 to 17.1 hours of turbine operation at full power-a substantial amount of energy storage.

Because of hydrogen embrittlement, it may not be possible to make the tower out of currently used alloys. A liner may be required, or it may be necessary to use alloys that are less sensitive to hydrogen embrittlement. These measures would probably increase the tower cost.

\section{The Complete System (Including Regeneration)}

A complete system might include the turbine, an electrolyzer, a battery, and a generation source such as a fuel cell or combustion device. Integrating these devices into the turbine again provides additional opportunities for optimization (Figure 4).

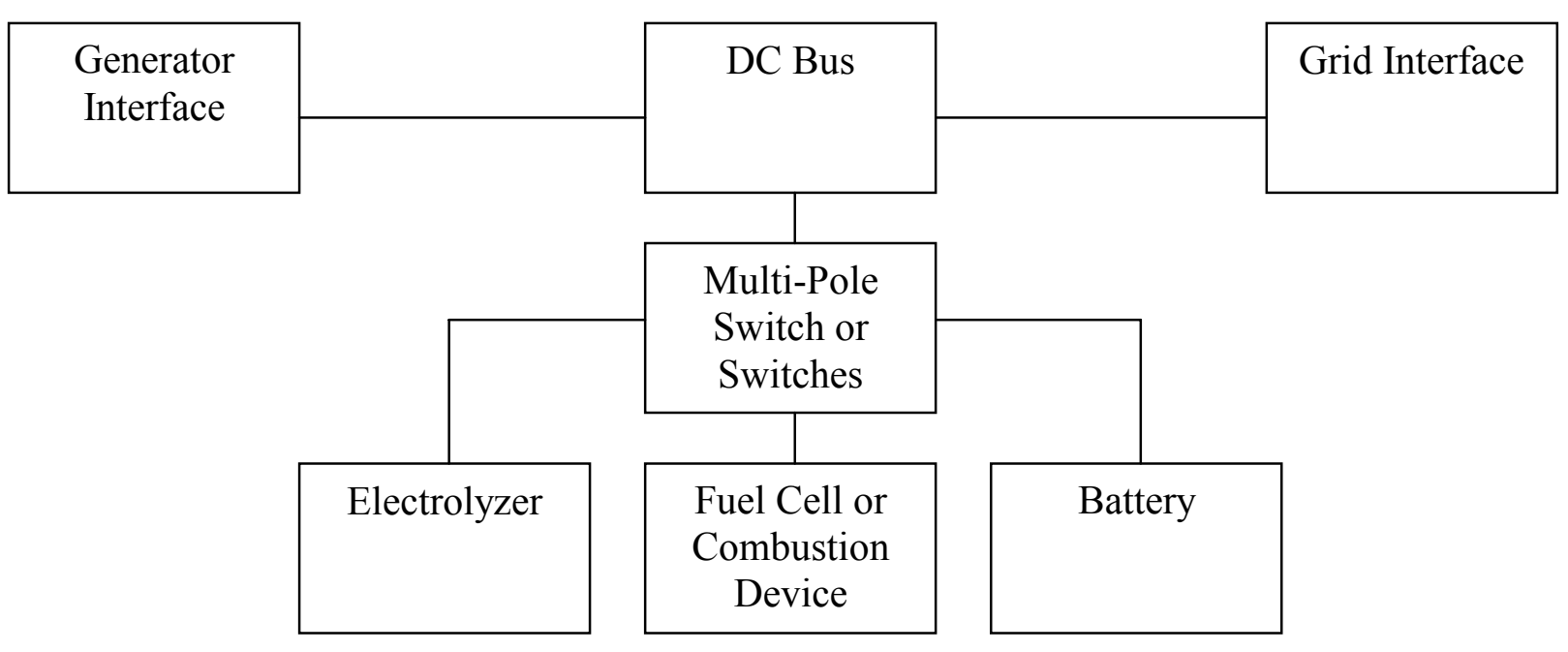

Figure 4. Full system layout.

The fuel cell or combustion device would be controlled by throttling or some other mechanical or chemical means, and the battery and electrolyzer would be controlled by the DC bus voltage and therefore by the turbine controller. The multi-pole switch would choose which device to connect to the DC bus, possibly connecting both the fuel cell and the battery at the same time.

For the full system, several components would be used more than once. Most notably, the power electronics and turbine controller would be used for all devices, with only the addition of a switch or contactor for each device. The tower could be used to store and release hydrogen from the electrolyzer and fuel cell. If the battery were of the nickel-hydrogen type, the tower could be used for this storage as well. Additionally, the wind farm hydrogen collection grid could be used to shuttle hydrogen from turbine to turbine and from turbine to pipeline and back, thereby increasing the available options for hydrogen storage, sale, and purchase. 


\section{System Optimization}

Including the afore-mentioned components into a wind energy power plant opens several avenues for total system optimization and site-specific customization. Sizing of the components, the way in which they are controlled, and certain turbine design parameters are variables that can be utilized in a total system optimization.

An example of one possible alteration is shown in Figure 5. In this example, a standard 750-kW wind turbine is depicted by the far left bar. All the energy generated from this turbine is transferred to the grid. As one moves to the right and the rated to mean wind speed ratio increases (i.e., a larger generator is used), more energy is generated, but the turbine also costs more. However, all of this additional energy is transferred to hydrogen generation. In the second and third sets of bars, the rating of the grid is decreased to $500 \mathrm{~kW}$ and $250 \mathrm{~kW}$. The grid rating is the maximum amount of power that can be transferred directly from the turbine to the grid. By decreasing the grid rating but not changing the turbine rating, more hydrogen is produced to make up the difference. This has the secondary effect of increasing the grid capacity factor. This example is only one of a myriad of possibilities for such a system. Even more opportunities are available if a regeneration device and/or a battery are included.

Electrical and Hydrogen Energy Collection

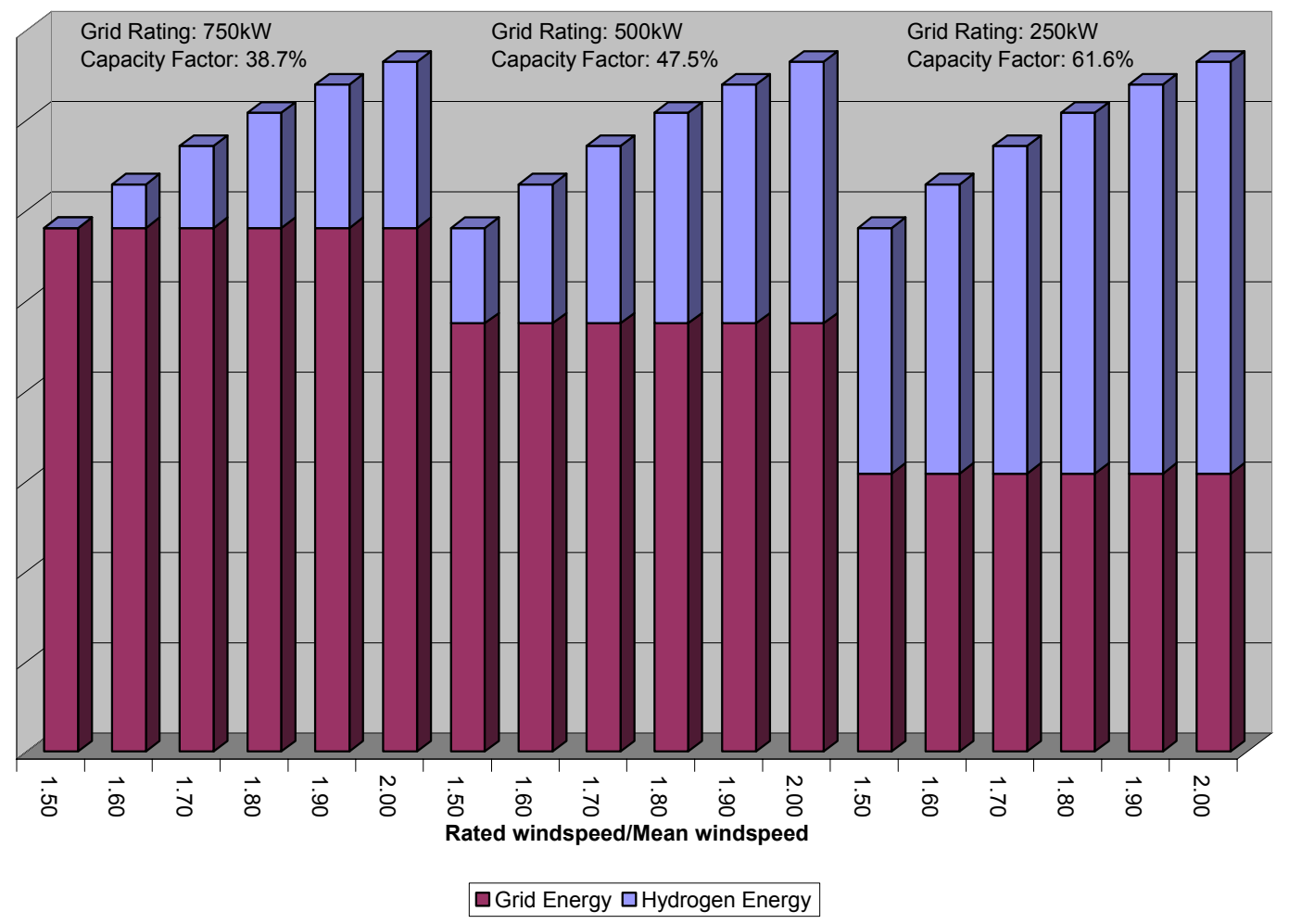

Figure 5. Adding hydrogen generation allows an increase in both energy captured and capacity factor. 


\section{Conclusion}

It is possible to efficiently connect multiple hydrogen-generating and -consuming devices to a modern variable-speed wind turbine without substantial additional complexity in the electrical power control system. In fact, it may be possible to connect an electrolyzer, regeneration device, and battery to an existing turbine design with only the addition of some switches and protection devices and no additional power electronics. By reusing existing wind turbine components in this way, significant total system cost savings can be achieved.

A wind energy system that includes an integrated hydrogen system also provides grid integration benefits. By including components whose energy consumption or production can be controlled, dispatchability is added to the wind energy power plant system. This dispatchability can be used to provide power at peak times of the day or year or to provide other ancillary services to the grid. In addition, it may be possible to reduce transmission line capacity from the wind plant by using the hydrogen system to "clip the power peaks" of the wind output. In this way, the grid capacity factor would be increased. With regeneration or batteries added, capacity factor would be increased even more.

One of the more exciting prospects for adding hydrogen components to a wind energy plant is the increased number of available options for site-specific optimization. For example, one might choose to provide more electricity and less hydrogen if the winds are steady and grid needs are high (as in California). One might also choose to produce more hydrogen and less electricity in locations with strong winds but small electrical loads (as in North Dakota). Even the type of grid available could influence the system optimization. Weak grids might need more hydrogen-based regeneration or more battery power when compared to stronger grids so that the wind plant could be dispatched when necessary to support the weaker grid.

The addition of hydrogen to conventional renewable power generation offers numerous advantages over stand-alone systems. Elimination of redundant systems, enhanced efficiency, improved performance capability, and opportunities to provide optimized application specific design are just a few of the possibilities. Future in-depth analyses and systems integration studies will prove invaluable in determining the specific configurations and applications providing the lowest cost of energy. 


\section{REPORT DOCUMENTATION PAGE}

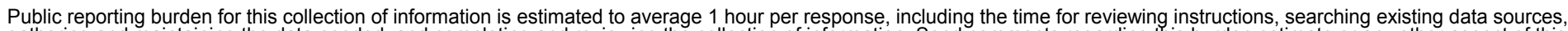

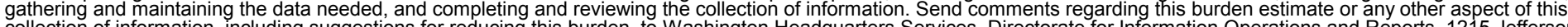
Davis Highway, Suite 1204, Arlington, VA 22202-4302, and to the Office of Management and Budget, Paperwork Reduction Project (0704-0188), Washington, DC 20503.
1. AGENCY USE ONLY (Leave blank)
2. REPORT DATE
3. REPORT TYPE AND DATES COVERED

June 2003

Technical Report

4. TITLE AND SUBTITLE

5. FUNDING NUMBERS

Optimized Hydrogen and Electricity Generation from Wind

6. $\operatorname{AUTHOR}(\mathrm{S})$

L.J. Fingersh

7. PERFORMING ORGANIZATION NAME(S) AND ADDRESS(ES)

National Renewable Energy Laboratory

1617 Cole Blvd.

Golden, CO 80401-3393

9. SPONSORING/MONITORING AGENCY NAME(S) AND ADDRESS(ES)

WER3.3250

8. PERFORMING ORGANIZATION REPORT NUMBER

NREL/TP-500-34364

10. SPONSORING/MONITORING AGENCY REPORT NUMBER

11. SUPPLEMENTARY NOTES

12a. DISTRIBUTION/AVAILABILITY STATEMENT

National Technical Information Service

12b. DISTRIBUTION CODE

U.S. Department of Commerce

5285 Port Royal Road

Springfield, VA 22161

13. ABSTRACT (Maximum 200 words)

Several optimizations can be employed to create hydrogen or hydrogen and electricity from a wind energy source. The key element in hydrogen production from any electrical source is an electrolyzer to convert water and electricity into hydrogen and oxygen.

Modern wind turbines employ a control system used in conjunction with power electronics in order to connect to the grid. It may be possible to use the turbine's controller and power electronics system to operate the electrolyzer as well, thereby eliminating component duplication. Such a coupled system would reduce the overall cost of independent stand-alone systems. Electrical power provided to the electrolyzer in such a system would be controllable with excess power provided to the grid. Thus, a combined system would have more dispatchability than a wind-electric turbine alone. Such dispatchability might be used to provide the utility with a measure of control over the wind farm's total output that does not exist in current wind farms.

Produced hydrogen needs to be stored, transported, and/or regenerated into electricity offering additional synergies. This paper examines several coupled systems that offer enhanced capability, efficiency, and cost reduction opportunities over stand-alone component systems.

14. SUBJECT TERMS

wind energy; wind farm; wind turbine; hydrogen; electricity generation; electrolyzer

15. NUMBER OF PAGES

16. PRICE CODE

17. SECURITY CLASSIFICATION OF REPORT Unclassified
18. SECURITY CLASSIFICATION OF THIS PAGE Unclassified
19. SECURITY CLASSIFICATION OF ABSTRACT Unclassified
20. LIMITATION OF ABSTRACT

UL 